\title{
GRASS WINTERING AND ITS IMPLICATIONS IN SOUTHLAND
}

\author{
R. E. HALFORD \\ Ministry of Agriaulture \& Fisheries, Invercargill
}

Summary

The development of grass wintering of breeding ewes in Southland is described. The changes that have been made are outlined, together with details of hogget and cattle systems. The physical and financial implications of grass wintering are discussed.

\section{INTRODUCTION}

IN THE PAST DECADE no management practice has had a greater impact on Southland farming than grass wintering. Its introduction has revitalized pasture production and management as well as substantially reducing winter feed costs.

Grass wintering developed largely from a dissatisfaction with swedes. Disease problems - e.g., clubroot - poor strikes, and the need to plough good pasture solely for swedes, caused farmers to turn to alternative wintering systems. Autumn-saved pasture and vacuum silage were tried but without a great deal of success.

Pasture decay through overspelling, the relative unpalatability of the saved grass and the slow regrowth after grazing were factors responsible for the failure of autumn-saved pasture. Vacuum silage lost favour after one year because of cost and mud problems.

In the mid-nineteen-sixties innovating farmers experimented with grass wintering using practices such as on-off grazing and set-stocking. It was not until 1967, however, that rotational grazing techniques were first employed. This occurred largely as a result of a visit by a Gisborne farm adviser, A. J. McNeur, who encouraged a few farmers to graze their ewes rotationally through the winter. The success of the practice provided the impetus to grass wintering in Southland.

\section{THE SYSTEM}

\section{Breeding Ewes}

Today, grass wintering of breeding ewes involves a slow rotation from some time after tupping through until lambing. De- 
pending upon individual mob and paddock sizes, temporary subdivision may be required in order to utilize efficiently the available feed. Each "block" is grazed from one to four days depending on climatic conditions and stocking rate. Back fencing is essential and hay may be fed.

Since its inception, an increasing number of farmers have changed to grass wintering. This trend is indirectly illustrated in Table 1 which shows the decline in swede seed sales in Southland from $1967-8$ to $1970-1$.

TABLE 1: SOUTHLAND SWEDE SEED SALES 1967-70 (ESTIMATED)

\begin{tabular}{|c|c|c|c|c|c|c|}
\hline Season & & & & & & $k g$ \\
\hline $1967-8$ & & & & $\ldots$ & $\ldots$ & 10,874 \\
\hline 1968.9 & . & & . & . & . & 10,848 \\
\hline 1969-70 & . & $\ldots$ & & $\because 1$ & & 10,565 \\
\hline $1970-1$ & $\ldots$ & . & $\ldots$ & & . & 6,993 \\
\hline
\end{tabular}

Changes that have evolved within the system have basically concerned the length of the rotation and the degree of temporary subdivision. Initial rotations were approximately 60 days but these have now been extended in order to incorporate more flexibility and to allow a longer period for regrowth.

The longer rotations have been achieved in one of two ways. Either the grazing pressure and hence the number of shifts have been increased, or the number of days spent on each "block" have been increased. This has given rise to two basic types of rotation, namely, low stock concentrations (490 to $740 / \mathrm{ha}$ ) and infrequent shifts (three to four days) and high stock concentrations (1,000 to $2,000 /$ ha) and frequent shifts (one to two days). Both have advantages and disadvantages.

The higher grazing pressure requires a greater labour input as more subdivision is required. However, walking and trampling damage are minimized so that less grass is fouled and better utilization is achieved. The shorter grazing period and the smaller amount of sward damage allows quicker regrowth.

Lower stock concentrations reduce the amount of subdivision but increase hay requirements. In extremely wet weather, more pasture damage occurs through greater stock movement.

\section{HOGGETS}

Farm observations and trials (Packard, 1970) indicate that hoggets can be wintered equally as well on grass as on swedes. 
Despite this, the practice has not gained wide acceptance. This is a reflection of two factors:

(1) A desire to grass-winter breeding ewes efficiently before attempting the system with hoggets.

(2) The effect of a widely published experiment at Invermay in which hoggets wintered on swedes had better growth rates than hoggets wintered on autumn-saved pasture (Drew, 1968).

Farmers wintering hoggets on grass are using a wide range of systems. These include set-stocking or rotational grazing on areas separate from the breeding ewes, rotational grazing ahead of the ewes, and the grazing of ewes and hoggets in one mob. The latter two systems are least preferred.

Hogget growth rates are penalized when hoggets have to compete with older sheep for the available feed. This is especially so when breeding ewes are being fed at maintenance or submaintenance levels. Grazing hoggets ahead of the ewes improves growth rates but requires greater managerial skill in order to avoid grass shortages at lambing,

The innovators have shown that hoggets can be successfully grass wintered. As farmers become more confident about wintering ewes on grass, greater acceptance of the hogget system will foilow.

\section{CATtie}

On the Southland plains, a rapidly growing industry has been the fattening of beef weaners. Following the success of grass wintering of sheep, thoughts turned to the feasibility of wintering weaners on grass.

Work on this aspect has been under way for the past two years. Preliminary results indicate that the efficiency of beef production can be substantially improved by grass wintering. Weight gains can be improved, winter feed costs reduced, and final carcass weights increased.

The principles are the same as for sheep, except that weaners are fed to gain weight through the winter. Essential requirements are a slow rotation, high stock concentrations (40 to 60/ha), daily shifts, back fencing and some form of pad for off-paddock feeding in extremely wet weather.

By providing a daily ration of grass, weight gains of $0.45 \mathrm{~kg}$ per day have been achieved with $185 \mathrm{~kg}$ weaners, from June to 
August. Over this period hay usage has been reduced to 8 or 9 bales per head. Carcass weights of $250 \mathrm{~kg}$ have been achieved by mid February.

\section{IMPLICATIONS}

Research has shown that frequent hard grazing during the winter reduces both winter and early spring production (Brown and Harris, 1970). Under the rotational system of grass wintering it is probable that the longer spell between grazings offsets the effects of the severe baring of the pasture.

Grazing pastures during the winter reduces the detrimental effects of overspelling and the subsequent loss of feed through decomposition. The fertility cycle is maintained as dung and urine are deposited evenly on paddocks in the rotation. Winter and early spring growth are increased (Brougham, 1966).

The hard grazing and treading associated with grass wintering leads to a change in pasture composition. Ryegrasses (Loliurn spp.) become dominant, while weed grasses such as Yorkshire fog (Holcus lanatus), browntop (Agrost is tenuis), sweet vernal (Anthoxanthum odoratum) and bromus mollis (Bromus mollis) are suppressed.

Associated with this change is a change in pasture density. Pastures alter over a period of time from dense swards to more open ryegrass/white clover swards. These pastures cannot withstand as easily the treading effects of high stock concentrations. Under extremely wet conditions the soil surface turns to a "slurry" more readily than under the denser browntop swards.

This effect is due in part to a reduction in the quantity of dead plant material in the pasture. In dense browntop swards, this material acts as a cushion and slows the' breakdown of the soil surface under high stock concentrations.

On farms where grass wintering has been practised for a number of years, this "sluriry effect" can be prevented simply by shifting the sheep more frequently in wet weather.

Most experimental evidence (Edmond, 1958; Brown, 1968) indicates that repeated treading on short pasture will seriously reduce pasture productivity. Thkse experiments, however, differ from the situation that occurs under a grass wintering system in Southland. Treading was based on the assumption that a ewe travels $2.73 \mathrm{~km}$ in one day. Under farm conditions the amount of walking is very much restricted by the high stock concentrations. This, together with the greater herbage cover, the fre- 
quent shifts, and the long grazing interval, minimizes the effect of treading on pasture productivity.

This winter, saturated ground conditions, and very cold nights with driving rain and sleet, resulted in serious pasture damage on areas where stock congregated for shelter. Under these conditions sacrifice areas, such as wheat stubble or roadsides, are essential in order to prevent pugging and consequent pasture damage (Edmond, 1962).

Grass wintering has emphasized the importance of subdivision as a means of achieving maximum pasture utilization. This has had a twofold effect. There has been a permanent reduction in paddock size on many farms, while high winter grazing pressures have been achieved through temporary subdivision. In most cases this temporary subdivision has been in the form of mains electric fences.

Summer and autumn pasture management has been influenced by the realization that grass wintering requires actively growing pastures. Where growth cannot be controlled by stock, or by closing for hay, topping is being carried out to prevent the formation of seedheads.

\section{FINANCIAL BENEFITS}

Grass wintering is a management technique which not only reduces the cost of production but also leads to an increase in output.

Winter feed costs are reduced through the elimination of swedes and an associated reduction in hay usage. For 1,000 ewes this can represent a saving of 4 ha of swedes and 500 bales of hay. At a cost of $\$ 25 /$ ha for swedes and 40 cents per bale for hay, this is equivalent to an increase in net profit of 30 cents per ewe. If regrassing is charged against the swede crop (as would be the case in a swedes to choumoellier to grass rotation) the saving in winter feed costs increases to 45 cents per ewe.

By not sowing swedes, an additional grass paddock becomes available for almost a whole year. Utilization of this paddock either through grazing extra stock or through an extra crop of wheat represents "additional profits" accruing from grass wintering.

The extra crop of wheat cannot, however, be entirely credited as the opportunity cost of growing swedes because it is sown three months earlier. On most farms these three months are the most critical period for grass growth and set the year's stocking 
rate in many farmers' minds. Hence an extra wheat crop may reduce the stock numbers it is possible to carry in this period.

Wintering on swedes meant that ewes constitutionally sound but with no teeth had to be culled. Under a grass wintering system these ewes can be retained as they are wintered on feed that they can utilize. This effectively reduces the culling rate and therefore the cost of replacement.

On developed farms, grass wintering avoids the necessity to plough good pastures solely for the purpose of growing swedes. On lower fertility farms, poor pasture can be rejuvenated thereby reducing the need to resow. There are cases on record that indicate it is possible to change run-out ryegrass pastures carrying 10 ewes/ha to pastures capable of carrying 17 ewes/ha.

As October is the critical month for grass, the extra production (Brown and Harris, 1970) resulting from rotational grazing enables additional stock to be carried. Production from these stock increases gross income.

The more even plane of nutrition resulting from grass wintering improves wool quality and wool weight, thereby increasing gross income.

For individual farms only some of the cost savings and income gains that have been mentioned will be applicable. Illustrations of these are given in Table 2.

TABLE 2: FINANCIAL GAIN FROM GRASS WINTERING

\begin{tabular}{|c|c|c|c|}
\hline Farm & $\begin{array}{l}\text { Area } \\
\text { (ha) }\end{array}$ & $\begin{array}{c}\text { Ewe } \\
\text { Equivalents }\end{array}$ & $\begin{array}{l}\text { Financial } \\
\text { Gain (\$) }\end{array}$ \\
\hline$-\overline{\mathrm{A}}--$ & 76.9 & 1,180 & 900 \\
\hline $\mathrm{B}$ & 125.8 & 2,060 & 890 \\
\hline C & 97.1 & 1,546 & 430 \\
\hline $\mathrm{D}$ & 100.7 & 1,900 & 1,720 \\
\hline
\end{tabular}

\section{CONCLUSION}

The past five years have seen a slow but steady departure from swede to grass wintering. This has occurred largely as a result of the considerable physical and financial advantages inherent in wintering on grass. These advantages, together with the success of the system under extremely wet conditions of last winter, indicate that this trend will continue. While swedes will still have a place on some farms for many years, it is conceivable that in the future the Southland plain will come to be regarded as the plain of all grass and no swedes. 


\section{ACKNOWLEDGEMENT}

I wish to thank A. Auld, Wrightson-NMA, Invercargill, for the use of unpublished Southland swede seed sale data.

\section{REFERENCES}

Brcugham, R. W., 1966: Dairyfmg A.: 99-110.

Brown, K. R., 1968: N.z. $J l$ agric. Res., 11: 131.

Brown, K. R.; Harris, A. J., 1970: Proc. N.Z. Grassld Ass., 32: 191.

Drew, K. R., 1968: Proc, N.Z. Soc. Anim. Prod., 28: 94.

Edmond, D. B., 19.58: N.Z. 31 agric. Res., 1: 319

- 1962: Ibid., 5: 389.

Packard, P. M., 1970: N.Z. Farmer, 11: 26. 